\title{
Hepatic pathology in Capillaria hepatica infected mice
}

\author{
Patologia hepática em camundongos infectados pela Capillaria hepatica
}

\author{
Bruna Magalhães Gotardo', Rodrigo Guimarães Andrade ${ }^{1}$ and Zilton A. Andrade ${ }^{2}$
}

\begin{abstract}
Septal fibrosis of the liver regularly develops in rats infected with Capillaria hepatica. To find out whether such fibrosis also occurs in mice, 20 animals were submitted to infection with either 100 or 300 embryonated eggs and histologically examined after several periods of time, from 30 to 110 days afterwards. Results showed that mice developed acute, severe, diffuse and focal hepatic lesions that were soon modulated to focal areas of fibrosis containing eggs and worm remnants, despite the fact that a few worms remained alive, at least up to 110 days after inoculation. Areas of perisinusoidal fibrosis appeared in the proximity and around focal parasitic lesions, but clear-cut septal fibrosis was not observed. Why septal fibrosis forms in rats, but not in mice during $\mathrm{C}$. hepatica infection, only further studies can clarify. Mice seem to show better host/ parasite relationship than rats in regard to $\mathrm{C}$. hepatica infection.
\end{abstract}

Key-words: Capillaria hepatica. Hepatic capillariasis in mice. Septal fibrosis.

Resumo A fibrose septal do fígado se desenvolve regularmente em ratos infectados pela Capillaria hepatica. Com o fito de se verificar se tal tipo de fibrose também se desenvolve em camundongos, 20 animais foram infectados com 100 ou 300 ovos embrionados e examinados histologicamente em vários períodos de tempo, entre 30 até 110 dias após inoculação. Os resultados demonstraram que os camundongos desenvolvem inicialmente uma intensa hepatite aguda, difusa e focal, mas logo estas lesões são moduladas, desaparecendo a hepatite reacional difusa e persistindo as lesões em torno de ovos e restos de vermes. Alguns poucos vermes sobreviveram por todo o período experimental. Embora a fibrose perisinusoidal tenha aparecido em torno das lesões fibróticas focais, a fibrose septal não foi observada. Não se sabe por que a fibrose septal se forma no rato infectado por $\mathrm{C}$. hepatica, mas não no camundongo, mas o assunto merece investigação, pois importantes aspectos da fibrogênese hepática poderiam estar implicados. Os camundongos parecem melhor adaptados à $\mathrm{C}$. hepatica que os ratos; nos primeiros, a infecção é nitidamente autolimitada.

Palavras-chaves: Capillaria hepatica. Capilaríase hepática em camundongos. Fibrose septal.

As first described by Ferreira \& Andrade ${ }^{7}$, chronic infection of rats with the helminth Capillaria hepatica is regularly associated with hepatic septal fibrosis. Such fibrosis appears in all rats with moderate to severe infection, exhibits a progressive course toward cirrhosis, and, oddly enough, starts when the focal parasite-dependent lesions are becoming encapsulated and undergoing resorption.
In addition to being a frequent and nonspecific change in several chronic liver diseases of man, septal fibrosis is the outstanding change in so-called incomplete septal cirrhosis, a condition presenting bad prognosis and of unknown etiology ${ }^{314}$.

The mouse is one of the most susceptible host for $C$. hepatica. Whether this rodent can also develop septal fibrosis has not been determined,

\footnotetext{
1. Estagiários acadêmicos do Centro de Pesquisas Gonçalo Moniz; 2. Laboratório de Patologia Experimental do Centro de Pesquisas Gonçalo Moniz da Fundação Oswaldo Cruz (FIOCRUZ), Salvador, BA.

Address to: Dr. Zilton A. Andrade. Laboratório de Patologia Experimental/CPqGM/FIOCRUZ. R. Valdemar Falcão 121, 40295-001 Salvador, BA, Brasil.

Fax: 5571 356-2155.

e-mail: zilton@cpqgm.fiocruz.br

Recebido para publicação em 24/2/2000.
} 
but the availability of a murine model of septal fibrosis would be advantageous for future studies. The mouse has been thoroughly investigated on its immunological system, is more economical and easier to work with than the rat, not counting the possibilities for the use of transgenic strains and the availability of commercial kits for cellmarkers, adhesion molecules, cytokines, chemokines, etc.
Present work was primarily planned to observe whether septal fibrosis of the liver would develop in the mouse infected with $C$. hepatica, as it does in the rat. Although the answer to this question was negative, present investigation revealed other interesting features of the hepatic pathology of capillariasis in mice, apparently not hitherto considered, that form the basis of the present report.

\section{MATERIAL AND METHODS}

Twenty young Swiss mice of both sexes, maintained on a balanced commercial chow and water ad libitum were used. Infection was made with embryonated eggs of $C$. hepatica. The animals were separated into two groups of ten: one of them inoculated with 100 eggs each, and the other with 300 eggs. The eggs were obtained from the livers of rats experimentally infected with C. hepatica, after extraction in a warring blender at $1,000 / \mathrm{rpm}$ rotation during 1 minute, followed by repeated washing, by means of centrifugation and precipitation in distilled water. After a 28-30 day period allowed for maturation at room temperature $\left(24-28^{\circ} \mathrm{C}\right)$, the eggs became embryonated and were ready to be used. Administration of eggs was made by gavage, the inoculum for each animal being suspended in $0.7 \mathrm{ml}$ of distilled water.

Animals were killed, two at a time, one from each inoculum group, initially with an interval of 7 days and later of 15 days, starting thirty days after inoculation. At the time of sacrifice the animals were previously anesthetized with ether and exsanguinated by severing of the abdominal aorta. Necropsies were complete and included a thorough inspection of the liver, spleen and the abdominal cavity. Body and liver weights were recorded. Fragments of the liver were fixed in phosphate-buffered $10 \%$ formalin (Millonig) and in Bouin's fluid for paraffin embedding and sectioning. Sections were stained with hematoxylin and eosin, and with the sirius-red method for collagen.

The presence of antigenic material from $C$. hepatica was search by the method of indirect immunofluorescence. Deparaffinized liver sections were treated with anti- $C$. hepatica serum, diluted in saline 1:5, 1:10,1:25 and 1:100. This anti-serum was obtained from experimentally infected rabbits. Secondary antibody was a fluoresceinated goat anti-rabbit serum, diluted 1:40 in PBS mixed with a small amount of Evans blue to cut non-specific background fluorescence. Controls included sections treated with the fluoresceinated secondary antibody only and others in which the primary antibody was replaced by normal pig serum.

\section{RESULTS}

Gross examination. Animals sacrificed at 30 , 38 and 45 days after inoculation presented marked hepato-splenomegaly, but this finding tended to subside afterwards. Around the $95^{\text {th }}$ and $110^{\text {th }}$ days the spleen and liver sizes were observed to be within normal limits (Figure 1).

The liver capsule was always smooth, distended and transparent, disclosing whitish, small, irregular areas of discoloration underneath. These lesions tended to become small confluent dots with time, proportionally to the decreasing of hepatomegaly. They were more evident in the animals killed during the early period of infection (30-45 days after inoculation), especially in those that received 300 eggs. Later, no significant difference was noted between animals infected with 300 or 100 eggs. Variation of body weight for the two groups can be observed in Figure 2. Similar to the gross changes described, the ponderal curve initially showed differences between the groups, but this tended to disappear toward the end of experimental time.

Histology. Changes in early infection were dominated by the presence of adult or immature worms, alive or dead, exhibiting variable degrees of disintegration, often with many eggs around. Tissue reaction consisted of a marked cellular infiltration, deposit of hyaline material and the presence of coagulative and purulent necrosis (Figure 3A). Inflammatory cells were mainly mononuclear leukocytes, although a great deal of polymorphonuclear eosinophils were seen in areas of necrosis. Besides multifocal reactions around parasites and their debris, a diffuse 


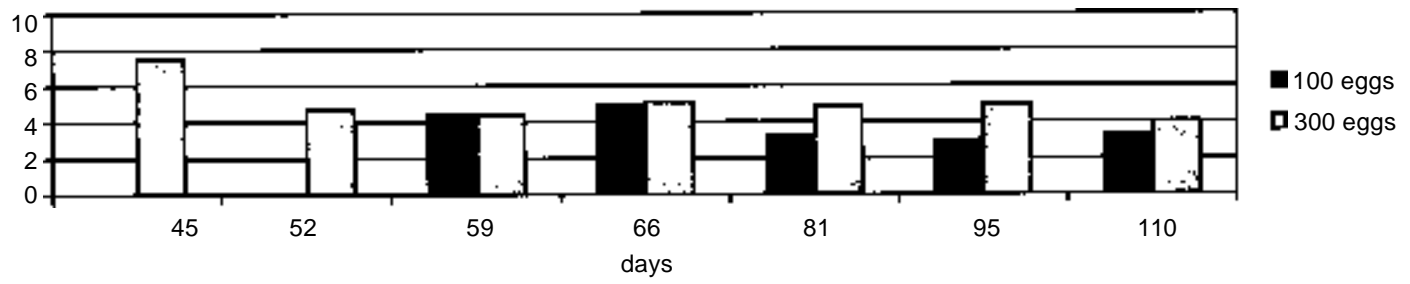

Figure 1 - Weight of the liver (grams) in relation to date of sacrifice and inoculum.

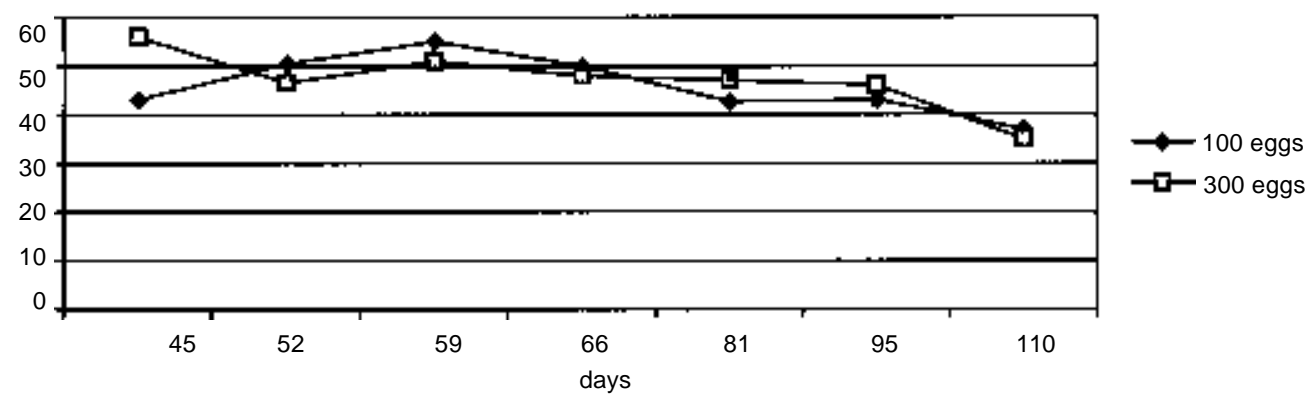

Figure 2 - Evolution of body weight of the animals (in grams) in relation to date of sacrifice and inoculum.

reaction was present in the liver (reactive hepatitis). This was represented by sinusoidal leukocytosis, parenchymal single-cell and focal necrosis, apoptosis plus periportal and pericentral leukocytic infiltrations. Evolution of all these lesions was characterized by gradual improvement, first leading to the disappearance of the reactive hepatitis changes and later on by progressive fibrosis, encapsulation and retraction of the focal parasite-dependent lesions. Fibrosis underwent progressive resorption during late infection. Formation of septal fibrosis was rarely seen, this change being occasional, never prominent. Perisinusoidal fibrosis was seen around focal fibrotic lesions, forming radiating short sprouts (Figure 3B). These short projections from the focal granulomatous parasite-dependent lesions usually disappeared in more chronic infection. Not only perisinusoidal fibrosis, but also capsular fibrous tissue became less and less dense with time, even disappearing later on, when eggs were seen to lay in direct contact with normal-looking hepatocytes.(Figure $3 \mathrm{C}$ and $\mathrm{D}$ ).

In animals with 95-110 days of infection, it was still observed late fibrotic involuting lesions, side by side with areas containing sections of well preserved worms and their eggs, sometimes surrounded by central purulent necrosis, but usually with little or no inflammatory reaction around.

Imunofluorescence. A strong apple-green fluorescence was exhibited by eggs and adult worms, preserved or in disintegration, in sections treated with anti-Capillaria serum, even in the extreme dilution of 1:100, during all phases of the present experiment (Figure 3E). Controls showed essentially negative results (Figure 3F). Egg shells exhibited a yellowish auto-fluorescence. 

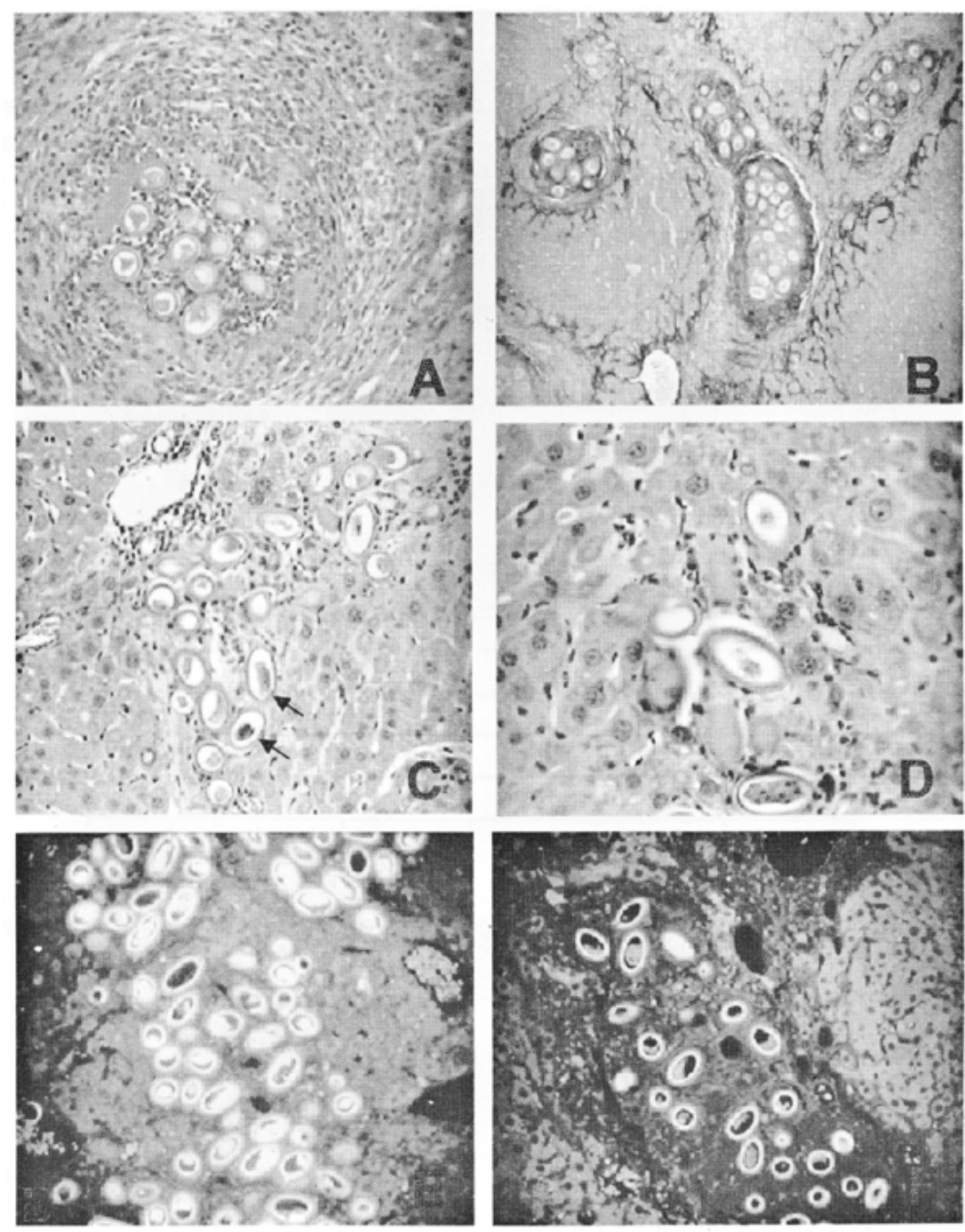

Figure 3A: Eggs of Capillaria hepatica appear surrounded with a halo of hyaline material and in the center of an acute inflammatory reaction containing a central zone of necrosis, infiltrated with disintegrated polymorphonuclear leukocytes (purulent necrosis). Thirty days after inoculation. HE, X150; $B$ : accumulated eggs in the liver are delimited by fibrous capsule, from the periphery of which short sprouts of perisinusoidal fibrosis are radiating. Sixty days of infection. Sirius-red staining, X100; C: Fibrotic reaction to parasite lesions exhibiting considerable degree of resorption in late infection, when the eggs lay almost in direct contact with hepatocytes (arrows). HE, X150; D: Detail showing eggs in close contact with liver cells in a mouse infection of 110-day duration. HE, X400: E: Positive immunofluorescent test showing strong antigenicity of eggs deposited in the liver of a mouse. Sixty days of infection. Rabbit anti-C. hepatica serum. X150; F: Control section. Specific anti-C. hepatica serum was replaced by normal pig serum. Only autofluorescence of egg shell is present. X150.

\section{DISCUSSION}

Contrary to what happens in rats, septal fibrosis of the liver is not a feature of the hepatic pathology produced by $C$. hepatica in mice. The course of infection in these two rodents is also different. While in rats the worms die out within a short time after infection ${ }^{811}$, in mice viable adult 
worms were found in the liver more than a 100 days following inoculation. Although high inocula have been used, there were no external signs of disease, such as ruffling of hair, weight loss, lack of activity, and practically no mortality, since only one death occurred, probably unrelated to $C$. hepatica infection. The infection is therefore well tolerated in mice, despite the transient acute phase, characterized by marked focal and diffuse inflammatory and degenerative hepatic changes. The reason why septal fibrosis does not develop in mice is difficult to explain. Pathogenesis of septal fibrosis itself is poorly understood at present. The model of septal fibrosis produced in rats by prolonged and repeated intraperitoneal injections of pig serum ${ }^{1}$ has been demonstrated to have an immunological basis ${ }^{4}$. Several studies have suggested that Kupffer cells produce fibrogenic cytokines, such as TGF- $\beta$, PDGF and TNF, that causes perisinusoidal Ito' cells to synthesize an excess of extracellular matrix ${ }^{5912}$. Persistent, sequestered $C$. hepatica antigens inside the liver have been claimed as the immunopathological pathway to septal fibrosis in rats $^{7}$. Such antigens are also present in murine capillariasis, as here demonstrated. For some unknown reason the putative immunological mechanism responsible for septal fibrosis is not fully operative in mice. Perisinusoidal fibrosis does appear in mice, suggesting a similar participation of local Ito' cells in mouse capillariasis. But this is represented by short radiating sprouts, formed around focal fibrotic parasitic lesions. Such septal fibrosis tends to undergo early resorption, as has been observed in a similar situation in experimental schistosomiasis under interferon treatment ${ }^{10}$.

Late, focal fibrotic lesions, containing immature eggs and worm debris, also undergo resorption with time. This process can be so extensive as to leave eggs and hepatocytes to lay in close contact with each other, without morphological evidences of damage. This is another indication of the well-succeeded adaptation of mice to $C$. hepatica.

Another striking difference from $C$. hepatica infection in rats and mice is the lack of nodular hepato-cellular regeneration in the latter. Although el-Nassery et $a^{6}$ in their study of mice capillariasis had mentioned parenchymal regeneration, in the present material this change was noted more by its almost absence, even in the presence of relatively large focal areas of coagulative hepatocellular necrosis.

It is interesting that several investigators in Australia have tried biological control of wild mice, a cause of heavy economical losses in cultivated fields, by exposing them to infection with $C$. hepatica. Their expectation was that the helminthic infection would result in both high mortality and decrease of fecundity of the wild mice ${ }^{16}$. However, results have so far been poor, probably because of the presence of a well-adjusted host-parasite relationship ${ }^{1315}$, as the present morphological findings suggest.

\section{REFERENCES}

1. Andrade ZA. Contribution to the study of septal fibrosis of the liver. International Journal of Experimental Pathology 72:553-562, 1991.

2. Barker SC, Singleton GR, Spratt DM. Can the nematode Capillaria hepatica regulate abundance in wild house mice? Results of enclosure experiments in southeastern Australia. Parasitology 103:439-449, 1991

3. Barnett JL, Appelman HD, Moseley RH. A familial form of incomplete septal cirrhosis. Gastroenterology 102:674$678,1992$.

4. Bhunchet E, Eishi Y, Wake K. Contribution of immune response to hepatic fibrosis by porcine serum. Hepatology 23:811-817, 1996.

5. Davis BH, Kresina TF. Hepatic fibrogenesis. Clinical and Laboratory Medicine 16:361-375, 1996

6. El Nassery SF, El Gebali WM, Oweiss NY. Capillaria hepatica: an experimental study of infection in white mice. Journal of the Egyptian Society of Parasitology 21:467$478,1991$.
7. Ferreira LA, Andrade ZA. Capillaria hepatica: a cause of septal fibrosis of the liver. Memórias do Instituto Oswaldo Cruz 88:441-447, 1993.

8. Galvão VA. Estudos sobre Capillaria hepatica: uma avaliação do seu papel patogênico para o homem. Memórias do Instituto Oswaldo Cruz 76:415-433, 1981.

9. Hautekeete ML, Geerts A. The hepatic stellate (Ito) cell: its role in human liver disease. Virchows Archiv 430:195207, 1997.

10. Lortart-Jacob H, Baltzer F, Desmoulière A, Peyrol S, Grimaud JA. Lobular - but not periovular - inihibition of collagen deposition in the liver of $S$. mansoni infected mice, using interferon-g. Journal of Hepatology 26:894903, 1997.

11. Luttermoser GW. Factors influencing the development and viability of the eggs of Capillaria hepatica in the rat and the mouse. American Journal of Hygiene 27:275289, 1938.

12. Maher JJ. Cytokines: overview. Seminars in Liver Disease 19:109-115, 1999. 
13. McCallum-HI. Evaluation of a nematode (Capillaria hepatica Bancroft, 1893) as a control agent for populations of house mice (Mus musculus domesticus Schwartz and Schwartz, 1943). Revue Scientifique et Technique 12:83-93, 1993.

14. Sciot R, Staessen D, Van Dame B, Van Steenbergen W, Fevery J, de Groote J, Desmet VJ. Incomplete septal cirrhosis: histopathological aspects. Histopathology 13:593-603, 1988.
15. Singleton GR, Chambers LK. A manipulative field experiment to examine the effect of Capillaria hepatica (Nematoda) on wild mouse populations in Southern Australia. International Journal of Parasitology 26:383398, 1996.

16. Spratt DM. The role of helminths in the biological control of mammals. International Journal of Parasitology 20:543$550,1990$. 